\title{
Cadmium (Cd) tolerance evaluation of three strains of microalgae of the genus Ankistrodesmus, Chlorella and Scenedesmus.
}

Evaluación de la tolerancia al cadmio (Cd) de tres cepas de microalgas de los géneros Ankistrodesmus, Chlorella y Scenedesmus.

\author{
D. Duque (iD ${ }^{1 *}$, C. Montoya (1D ${ }^{2}$, L.R. Botero (1) 1 \\ ${ }^{1}$ Grupo de Investigación en Biodiversidad, Biotecnología y Bioingeniería (GRINBIO), Universidad de Medellín, Centro de Laboratorios. \\ Laboratorio de Biotecnología. Carrera 87 \#30-65. C. P. 1983. Medellín, Colombia. \\ ${ }^{2}$ Grupo de bioprocesos, Facultad de Ingeniería, Universidad de Antioquia. calle 70 \# 52-21. C. P. 1226. Medellín, Colombia.
}

\section{CITE THIS ARTICLE AS:}

D. Duque, C. Montoya and

L. R. Botero. "Cadmium

(Cd) tolerance evaluation of three strains of microalgae of the genus

Ankistrodesmus, Chlorella and Scenedesmus", Revista Facultad de Ingeniería Universidad de Antioquia, 92, pp. 60-69, Jul-Sep 2019.

[Online]. Available:

https://www.doi.org/

10.17533/udea.redin. 20190523

\section{ARTICLE INFO:}

Received: March 16, 2018 Accepted: May 27, 2019 Available online: May 28, 2019

\section{KEYWORDS:}

Pollution control, biotechnology, environmental engineering, microbiology, water pollution

\section{Control de la} contaminación, biotecnología, ingeniería ambiental, microbiología, contaminación del agua
ABSTRACT: In order to assess tolerance to cadmium (Cd) for three Colombian native strains of microalgae belonging to the genus Ankistrodesmus, Chlorella and Scenedesmus the growth kinetics, the concentration of pigments, the total dry weight in media contaminated with cadmium in ranges between $0.0-15.0 \mathrm{mg} \mathrm{L}^{-1}$, and the median lethal concentration $\left(\mathrm{LC}_{50}\right)$ were determined. Additionally, for the more tolerant strains, Scenedesmus sp. and Chlorella sp., removal of $C d$ in media enriched with 1.0 and $7.0 \mathrm{mg} \mathrm{L}^{-1}$ contaminant was quantified. The study found that Scenedesmus sp was the strain that had the highest tolerance to cadmium generating $36.15 \mu \mathrm{g} \mathrm{mL}^{-1}$ of dry biomass at $3.5 \mathrm{mg} \mathrm{L}^{-1}$ of $\mathrm{Cd}_{\text {and }} \mathrm{LC}_{50} 20.89 \mathrm{mg} \mathrm{L}^{-1} \mathrm{Cd}$ after 12 days of culture. The highest percentage of removal of cadmium was $32 \%$ for Scenedesmus sp. Chlorella sp. presented good removal of $\mathrm{Cd}$ in cultures with low levels of metal and Ankistrodesmus sp. was the microalgae with less tolerance.

RESUMEN: Con el objetivo de evaluar la tolerancia al cadmio (Cd) de tres cepas de microalgas de los géneros Ankistrodesmus, Chlorella y Scenedesmus se determinó la cinética de crecimiento, concentración de pigmentos y peso seco total en medios contaminados con 0.0 - $15.0 \mathrm{mg} \mathrm{L}^{-1}$ de $\mathrm{Cd}$ y se calculó la concentración letal media $\left(\mathrm{CL}_{50}\right)$. Para las cepas Scenedesmus sp. y Chlorella sp., más tolerantes, se cuantificó la remoción de Cd en medios con 1.0 y $7.0 \mathrm{mg} \mathrm{L}^{-1}$ del contaminante. Siendo el mayor porcentaje de remoción de cadmio el $32 \%$ para Scenedesmus sp. Chlorella sp. presentó buena remoción en cultivos con niveles bajos del metal en el medio y Ankistrodesmus sp. fue la microalga con menor tolerancia al cadmio. Así mismo, se encontró que Scenedesmus sp. presentó la mayor tolerancia al cadmio generando $36.15 \mu \mathrm{g} \mathrm{mL}^{-1}$ de biomasa seca a $3.5 \mathrm{mg} \mathrm{L}^{-1}$ de $\mathrm{Cd}$ y una $\mathrm{CL}_{50}$ de 20.89 $\mathrm{mg} \mathrm{L}^{-1} \mathrm{Cd}$.

\section{Introduction}

Heavy metals are involved in all aspects of microbial growth and are mainly related to metabolic pathways [1]. There are some metals that are trace elements while others serve no essential function in microorganisms; however, when chemically similar elements may be replaced by some other [2]. Within cells, Cadmium (Cd) 
can damage the integrity of the cell membrane, block enzymes, inhibit transport systems and move items which are essential nutrients in cellular metabolism [3].

With the increase of industrial activities in recent decades, generation of waste polluted with heavy metals such as $\mathrm{Cd}$ has also increased. This contaminant has serious consequences in human health. Besides, heavy metals deteriorate aquatic ecosystems because they bioaccumulate easily inside the organisms affecting the food chain by a multiplier effect, a problem that is increased by their chemical stability towards biodegradation processes [4].

Cadmium is a heavy metal widely used in galvanoplasty industry, in semiconductor alloys for home appliances [5] and in the elaboration of pigments for textile industry and photography. At lower concentrations, $\mathrm{Cd}$ can come out harmless to humans and animals, but because of the bioaccumulation, it can damage the cell wall integrity, which affects organs such as kidneys, liver and lungs. It also causes disruption of mithocondria and endoplasmatic reticulum leading to the release of calcium within the cell, activating mechanisms of autophagy and apoptosis in some cells [6], and replacing elements which are essential nutrients in cell metabolism.

Bioremediation is a biological treatment which consists in the use of living organisms such as plants, microorganisms, fungus, and others, to degrade or transform pollutants. The use of biological treatments in some circumstances can turn out to be more convenient since it is not as expensive as other treatments and the resulting products are innocuous. Microalgae are organisms that can be used in this kind of process since they are not only food in aquatic environments, but they can also treat waste water from industrial activities [7]. Bioremediation with microalgae have been successful because these microorganisms are able to assimilate pollutants such as heavy metals and interact with them by the means of changes in the ion permeability, active exclusion, extracellular and intracellular chelation and cellular compartmentalization of the heavy metal $[8,9]$.

The present study aims to evaluate the potential of three native strains of microalgae from the genus Ankistrodesmus, Chlorella and Scenedesmus in the removal of cadmium in synthetic water looking to generate bioremediation processes using native microalgae.

\section{Experimentation}

\subsection{Microorganisms and culture conditions}

For the tests, three strains of native microalgae of Chlorella, Scenedesmus and Ankistrodesmus genus isolated from different sources of urban and rural water in Antioquia department were donated by the research team GRINBIO at University of Medellin. For maintenance and tests of tolerance, microalgae were grown in $250 \mathrm{~mL}$ Erlenmeyer containing $150 \mathrm{~mL}$ medium $3 \mathrm{~N}+\mathrm{V}$ BBM which comprises $\mathrm{NaNO}_{3}\left(0.75 \mathrm{~g} . \mathrm{L}^{-1}\right), \mathrm{CaCl}_{2} .2 \mathrm{H}_{2} \mathrm{O}\left(0.025 \mathrm{~g} . \mathrm{L}^{-1}\right), \mathrm{MgSO}_{4} .7 \mathrm{H}_{2} \mathrm{O}$ (0.075 g.L $\mathrm{L}^{-1}$ ), $\mathrm{K}_{2} \mathrm{HPO}_{4}\left(0.075 \mathrm{gl}^{-1} \mathrm{~L}^{-1}\right), \mathrm{KH}_{2} \mathrm{PO}_{4}\left(0.175 \mathrm{~g} . \mathrm{L}^{-1}\right.$ ), $\mathrm{NaCl}\left(0.025 \mathrm{~g} \cdot \mathrm{L}^{-1}\right), \quad \mathrm{Na}_{2} \mathrm{EDTA}_{4}$ (5 mg. $\left.\mathrm{L}^{-1}\right), \quad \mathrm{FeCl}_{3} \cdot 6 \mathrm{H}_{2} \mathrm{O}$ $\left(0.5874 \mathrm{mg} \cdot \mathrm{L}^{-1}\right), \mathrm{NaMoO}_{4}\left(0.024 \mathrm{mg} \cdot \mathrm{L}^{-1}\right), \mathrm{ZnCl}_{2} .6 \mathrm{H}_{2} \mathrm{O}$ (0.03mg. $\mathrm{L}^{-1}$ ), $\mathrm{MnCl}_{2} .4 \mathrm{H}_{2} \mathrm{O}\left(0.246 \mathrm{mg} \cdot \mathrm{L}^{-1}\right.$ ), $\mathrm{CoCl}_{2} 6 \mathrm{H}_{2} \mathrm{O}(0.012$ mg. $\left.\mathrm{L}^{-1}\right)$, Tiamina $\mathrm{HCl}\left(0.0012 \mathrm{mg} \cdot \mathrm{L}^{-1}\right)$ and Cianocobalamin [0.00001 mg. $\mathrm{L}^{-1}$ ] [10]. For Cd tolerance tests, cultures were prepared using a metal stock $1000 \mathrm{mg} \mathrm{L}^{-1}$ (brand $\mathrm{HACH} 囚$ ) added to the growth medium at different concentrations as shown below, except for the control group which did not have any trace of the heavy metal. Microalgae were cultured for 12 days under controlled laboratory conditions at $22^{\circ} \mathrm{C}$ and constant light $(4,100 \mathrm{~K}$ 17-Watt Cool White Fluorescent Tube Light Bulb) and for each sample concentration there were set two other flasks in order to ensure repeatability.

\subsection{Lethal concentration $\left(\mathrm{LC}_{50}\right)$ test}

The median lethal concentration $\left(L_{50}\right)$, which is a measure of the lethal effect of a substance in $50 \%$ of a population was used as the toxicological endpoint to find the acute effects of $\mathrm{Cd}$ in microalgae from an Probit analysis [11].

To determine $L_{50}$, culture media were contaminated with $0,2.0,4.0,8.0,12.0,16.0,25.0$ and $40.0 \mathrm{mg} \mathrm{L}^{-1}$ of $\mathrm{Cd}$ to the species of the genus Chlorella sp. and Scenedesmus sp. Lower doses of $0,2.0,4.0,6.0,8.0,12.0$ and $20.0 \mathrm{mg} \mathrm{L}^{-1}$ were used $\mathrm{Cd}$ for Ankistrodesmus sp, as previous studies (unpublished data) showed its sensitivity to metal.

Assays were performed in total volumes of $5 \mathrm{~mL}$ of isotonic solution $10.9 \% \mathrm{NaCl}$ inoculated with $10 \%$ microalgae culture, and contaminated with metal at different concentrations. The $\mathrm{LC}_{50}$ was evaluated after 96 hours of culture [12]. To determine the effect of time of exposure to $\mathrm{Cd}$ on the feasibility of microalgae, sampling after 0, 48 and 96 hours of culture were performed. Viability was quantified using the method of Evans blue staining [13]. Assays were performed in triplicate. During counting, the samples were kept in dark in order to avoid factors that promote the growth of microalgae. 


\subsection{Growth curves}

To determine the effect of $\mathrm{Cd}$ concentration on the kinetics of growth of microalgae culture at concentrations of 0.0 (control group) 0.5, 1.0, 3.5, 5.0, 7.0, 10.0 and $15.0 \mathrm{mg}$ $\mathrm{L}^{-1}$ of $\mathrm{Cd}$ were used. The cell density was determined by microscopic observation and cell counting using a Neubauer chamber. The dry biomass was found using gravimetric techniques proposed by Arredondo Vega \& Voltolina (2007) [14].

To determine the effect of $\mathrm{Cd}$ on the production of pigments (chlorophylls and carotenoids) $4.0 \mathrm{~mL}$ samples were taken every 3 days. The quantification of the pigments was performed spectrophotometrically following the methodology proposed by Parsons Strickland [15].

The specific growth rate is determined using equation (1) Where $x_{1}$ and $x_{2}$ are cellular concentrations at times $t_{1}$ and $t_{2}$ :

$$
\mu=\frac{\ln \left(x_{2} / x_{1}\right)}{t_{2}-t_{1}}
$$

\subsection{Determination of Cadmium removal percentage}

After evaluating the tolerance of the strains of microalgae to $\mathrm{Cd}$, the most resistant strains were cultivated in concentrations of 0.0 (control group) 1.0 and $7.0 \mathrm{mg} \mathrm{L}^{-1} \mathrm{Cd}$ in order to determine their ability to remove $\mathrm{Cd}$. Assays were performed in triplicate.

Cadmium analysis was made after 7 days to ensure that microalgae were in the final phase of growth near the stationary phase. The process of preservation and digesting for analysis of $\mathrm{Cd}$ was performed using the methods proposed in the Standard Methods of the examination of water and wastewater for dissolved metals [16] for which the samples were preserved at $4^{\circ} \mathrm{C}$, acidified with nitric acid, and then an acid digestion was performed. Finally, Cadmium determination was performed by mass spectrometry.

\subsection{Data analysis}

Differences between groups were analyzed from a multifactorial ANOVA and least significant difference test (LSD) Fisher. For testing $\mathrm{LC}_{50}$, a Probit analysis was applied. In both cases, the program STATGRAPHICS Centurion XVI was used.

\section{Results and discussion}

\subsection{Median lethal concentration ( $\left.\mathrm{LC}_{50}\right)$}

After 96 hours of culture, the analysis of $\mathrm{LC}_{50}$ showed values of $20.89 \mathrm{mg} \mathrm{L}^{-1}, 8.00 \mathrm{mg} \mathrm{L}^{-1}$ and $5.43 \mathrm{mg} \mathrm{L}^{-1}$ for Scenedesmus sp., Chlorella sp. and Ankistrodesmus sp. respectively ( $\mathrm{P}$-value $<0.05$ ) (Figure 1). Ankistrodesmus $\mathrm{sp}$. was the least tolerant microalgae to this particular heavy metal and in contrast Scenedesmus sp. presented the highest tolerance of the three genus studied. When comparing our results with those reported by other authors who found that cadmium, in concentration of $7.6 \mathrm{~g}$, decreases cell growth by $50 \%$, it is possible to evidence the tolerance of this microalgae [17]. In the case of Chlorella vulgaris, it has been reported that at concentrations varying from 5.1 to $15.72 \mathrm{mg} \mathrm{L}^{-1}$, this heavy metal causes acute toxicity evidenced in an inhibitory effect on the growth of this species [18], and comparing these results with the ones found in the present work, it can be said that Chlorella $\mathrm{sp}$. had a response to the exposure of $\mathrm{Cd}$ that is within the range mentioned above. However, the disparities on $\mathrm{LC}_{50}$ values found on the literature can be explained by the environmental conditions such as temperature, light, initial cellular density, and culture medium that were used in each of those experiments, which can alter the algae response towards $\mathrm{Cd}$ even if the same species and heavy metal are used [19]. Results confirm the importance of assessing toxicity in terms of Median Lethal Concentration $\left(L_{50}\right)$, because when exposing microalgae to a heavy metal such as $\mathrm{Cd}$, it is possible to generate interactions between these organisms and the heavy metal, which can cause different responses such as growth rate inhibition or cell death that are reflexed in the value of $\mathrm{LC}_{50}$ [20].

\subsection{Cadmium effect on the growth curves}

Regarding the toxicity of $\mathrm{Cd}$ for the three microalgae species in the case of Ankistrodesmus sp. it is possible to identify a reduction on the growth with the increase of the $\mathrm{Cd}$ concentration in the medium (Figure 2). It can be observed from the graphic that there are three groups of kinetics: The first group is represented by cultures with absence or lower $\mathrm{Cd}$ concentration $(0.0,0.5,1.0 \mathrm{mg}$ $\mathrm{L}^{-1}$ ). Control group (without heavy metal), reached the maximum biomass density of $4.00 \times 10^{5}$ cell mL $\mathrm{mL}^{-1}$ after 12 days of culture, when the death phase started. Cultures exposed to concentration of 0.5 and $1.0 \mathrm{mg} \mathrm{L}^{-1}$ of $\mathrm{Cd}$ have maximum densities of $3.75 \times 10^{5}$ cell mL ${ }^{-1}$ and $2.75 \times 10^{5}$ cell $\mathrm{mL}^{-1}$ after 9 days of culture, respectively. For these cultures a little affectation was manifested in an extension of the initial adaptation phase.

A second group of kinetics is represented by cultures with mean concentrations of $\mathrm{Cd}\left(3.5\right.$ y $\left.5.0 \mathrm{mg} \mathrm{L}^{-1}\right)$. They 

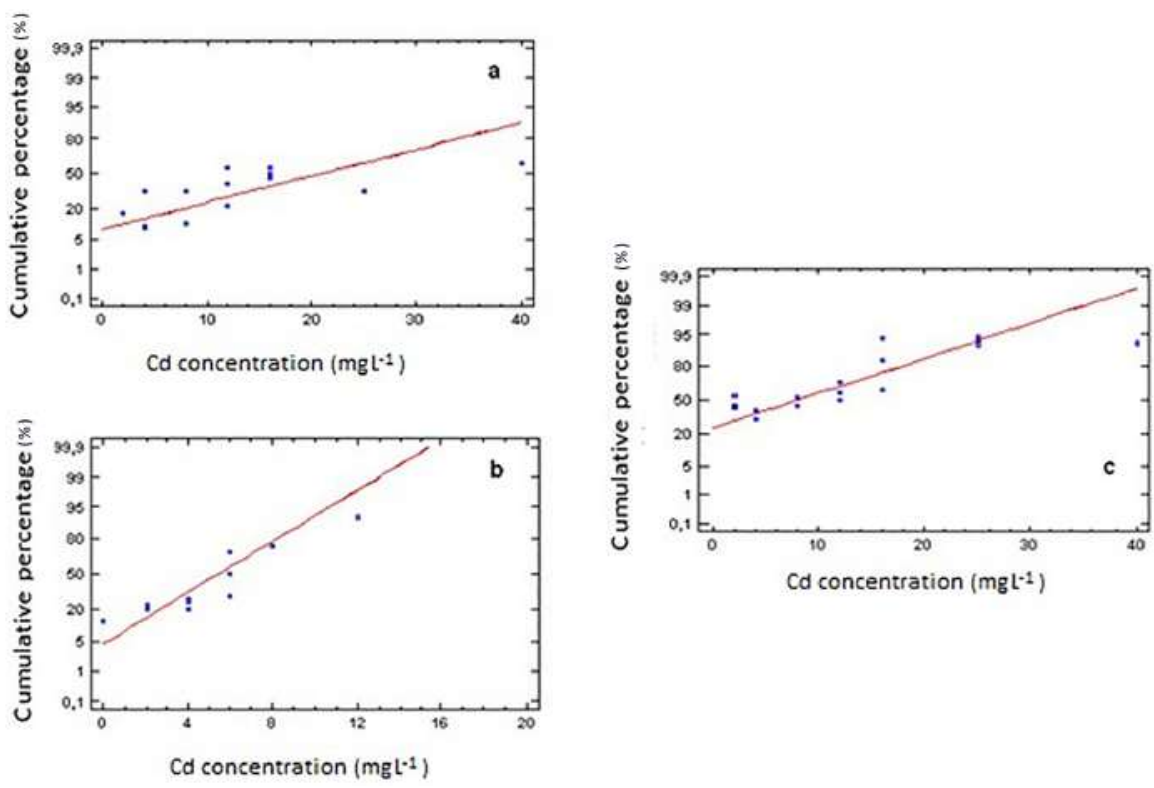

Figure 1 Probit regression graph that shows $L C_{50}$ of (a) Scenedesmus sp. $R^{2}=52.13$, (b) Ankistrodesmus sp $R^{2}=84.73$ and (c) Chlorella sp. $R^{2}=70.24$.

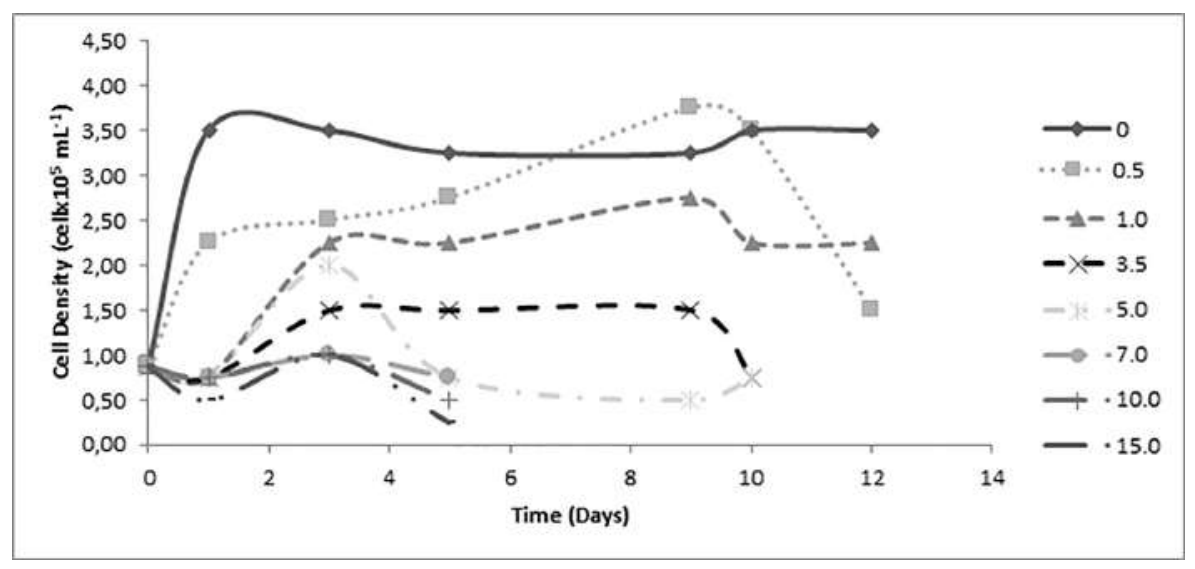

Figure 2 Effect of the concentration of $\mathrm{Cd}$ on the cellular density of Ankistrodesmus sp. during 12 days of culture

Table 1 LSD test for maximum cell density achieved by the microalgae (One-way ANOVA)

\begin{tabular}{lllllllll}
\hline $\begin{array}{l}\text { Cadmium } \\
\text { Concentration (mg L-1) }\end{array}$ & $\mathbf{0}$ & $\mathbf{0 . 5}$ & $\mathbf{1 . 0}$ & $\mathbf{3 . 5}$ & $\mathbf{5 . 0}$ & $\mathbf{7 . 0}$ & $\mathbf{1 0 . 0}$ & $\mathbf{1 5 . 0}$ \\
\hline Chlorella sp.** & $3.40^{\mathrm{a}}$ & $25.0 \mathrm{~b}$ & $7.60^{\mathrm{a}}$ & $2.02^{\mathrm{a}}$ & $2.50^{\mathrm{a}}$ & $1.80^{\mathrm{a}}$ & $0.85^{\mathrm{a}}$ & $0.92^{\mathrm{a}}$ \\
Ankistrodesmus sp.** & $0.40^{\mathrm{a}}$ & $0.37^{\mathrm{a}}$ & $0.35^{\mathrm{a}}$ & $0.20^{\mathrm{b}}$ & $0.20^{\mathrm{b}}$ & $0.17^{\mathrm{b}}$ & $0.15^{\mathrm{b}}$ & $0.12^{\mathrm{b}}$ \\
Scenecesmus sp.** $^{*}$ & $1.92^{\mathrm{a}}$ & $1.97^{\mathrm{a}}$ & $1.80^{\mathrm{a}}$ & $1.62^{\mathrm{a}}$ & $1.30^{\mathrm{a}}$ & $1.32^{\mathrm{a}}$ & $1.50^{\mathrm{a}}$ & $1.37^{\mathrm{a}}$ \\
\hline
\end{tabular}

*Same letter represent homogeneous groups within the specific genus. All values are in cells $\times 10^{6} \mathrm{~mL}^{-1}$.

reached the maximum biomass density of $2.00 \times 10^{5}$ cell $\mathrm{mL}^{-1}$ and $1.50 \times 10^{5}$ cell $\mathrm{mL}^{-1}$, respectively, after 3 days of culture, when cell growth is suspended. It is possible to infer that cells begin to die at concentrations of $5.0 \mathrm{mg} \mathrm{L}^{-1}$ of $\mathrm{Cd}$ because their growth is poor and they remain in the adaptation phase for ten days.
The third group of kinetics is represented by cultures with highest $\mathrm{Cd}$ concentration $\left(7.0,10.0,15.0 \mathrm{mg} \mathrm{L}^{-1}\right.$ ). These cultures have important affectations that are manifested with an initial cell death, an extension of the adaptation phase, and lower peaks of biomass densities around $1.00 \times 10^{5}$ cell mL $\mathrm{mL}^{-1}$ reached after 3 days. Although from the Lesser Significant Difference Test (LSD) of 
the one-way ANOVA it was ratified that the distinct $\mathrm{Cd}$ concentrations in the mediums have a significant influence on the population density $(\mathrm{P}$-value $<0.05)$ and growth rate of Ankistrodesmus sp. (P-value <0.05) (Table 1), the test clearly differentiates two groups of kinetics, in which cells at $0.0,0.5$ and $1.0 \mathrm{mg} \mathrm{L}^{-1}$ behave significantly different in terms of growth than the ones from the cultures of 3.5 $\mathrm{mgL}^{-1}$ of $\mathrm{Cd}$ and higher.

Generally speaking, growth of Scenedesmus sp. is more prosperous than Ankistrodesmus sp. reaching a maximum value of $1.9 \times 10^{6}$ Cells $\mathrm{mL}^{-1}$ after ten days of culture. In relation to toxicity, the $\mathrm{Cd}$ effects are lower for Scenedesmus sp. than Ankistrodesmus sp., evidenced in the analysis of the effects caused by the $\mathrm{Cd}$ on the growth of the cultures of Scenedesmus sp. performed by Fisher's LSD test where it did not show differentiation among treatments (Table 1). For this microalgae, the highest values of cellular density are observed at $0.5 \mathrm{mg}$ $\mathrm{L}^{-1}$ of $\mathrm{Cd}$. From Figure 3 , it is possible to identify three groups of kinetics for Scenedesmus sp. too. The first group is represented by cultures with absence or lower Cd concentration $\left(0.0,0.5,1.0 \mathrm{mg} \mathrm{L}^{-1}\right)$ which reached the maximum biomass density of $1.92 \times 10^{6}, 1.97 \times 10^{6}$ and $1.80 \times 10^{6}$ cell $\mathrm{mL}^{-1}$ after 12 days of culture, respectively, when the death face began. These three cultures have short initial phase of adaptation, evidencing its tolerance to low doses of the metal, where the highest values of population density are observed at $0.5 \mathrm{mg} \mathrm{L}^{-1}$ of $\mathrm{Cd}$. A second group of kinetics is represented by cultures with mean concentrations of $\mathrm{Cd}$ (3.5 y $5.0 \mathrm{mg} \mathrm{L}^{-1}$ ), they reached the maximum biomass density of $1.62 \times 10^{6}$ and $1.30 \times 10^{6}$ cell $\mathrm{mL}^{-1}$ after 5 and 7 days of culture respectively.

The third group of kinetics is represented by cultures with highest $\mathrm{Cd}$ concentration of $7.0,10.0,15.0 \mathrm{mg} \mathrm{L}^{-1}$ with the toxic effects evidenced by decreasing of the cellular density with values of $8.75 \times 10^{5}, 9.00 \times 10^{5}$ and $1.00 \times 10^{6}$ cell $\mathrm{mL}^{-1}$ at the end of the experiments.

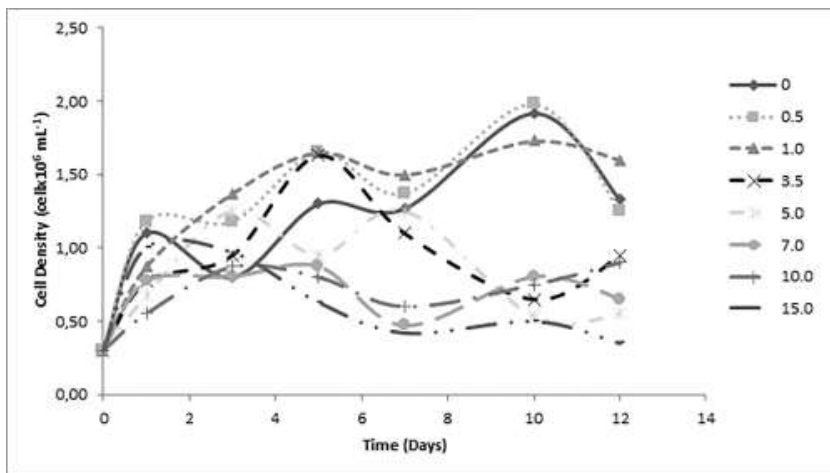

Figure 3 Effect of cadmium concentration on Scenedesmus sp. cell kinetics growing during 12 days of culture
The general growth of Chlorella sp. is higher than the growth of the other two strains of microalgae evaluated in this study reaching a maximum value of $3.8 \times 10^{6}$ cell $\mathrm{mL}^{-1}$ after ten days of culture under control conditions without Cd (Figure 4). Regarding toxicity of Cd, Chlorella sp. at low concentrations of 0.5 and $1.0 \mathrm{mg} \mathrm{L}^{-1}$ of $\mathrm{Cd}$, has a growth-enhancing effect that raises growth peaks to values of $2.52 \times 10^{7}$ and $7.65 \times 10^{6}$ cell mL $\mathrm{m}^{-1}$, respectively. According to Fisher's LSD test made for Chlorella sp. differences between the means of population density for each concentration of the heavy metal are not significant with the exception of the treatment at $\mathrm{Cd}$ concentration of $0.5 \mathrm{mg} \mathrm{L}^{-1}$, which reported a higher value indicating that $\mathrm{Cd}$ at this concentration has an important promotion of cellular growth (Table 1). Besides, all kinetics, except that obtained using $0.5 \mathrm{mg} \mathrm{L}^{-1}$ of $\mathrm{Cd}$, have similar tendencies to the control, and the cultures with 10.0 and $15.0 \mathrm{mg} \mathrm{L}^{-1}$ $\mathrm{Cd}$ entered death phase and were suspended on day 9 evidencing a toxic effect of this heavy metal.

In general, growth curves of the cultures indicate that the biomass increases through time, and because of the conditions of the environment in which cells developed, the speed of that growth varies; different phases are exhibited describing the changes of cell concentration. In the present study, the phase of adaptation of the microorganisms to the environment is not shown llag phase) due to its brief duration of less than 24 hours. Exponential phase, where there are no growth-limiting factors, and stationary phase, in which growth-rate and death-rate are equal, varied according to the $\mathrm{Cd}$ concentration in the medium and how fast the death phase was achieved, in which death-rate surpassed the growth-rate. Cultures used in the present work did not manifest inhibition of the biomass increase in mediums with $\mathrm{Cd}$ at $0.5 \mathrm{mg} \mathrm{L}^{-1}$. Even though for Scenedesmus sp. and Ankistrodesmus sp. kinetics behavior at the mentioned concentration were not very different from the control group, in the case of Chlorella sp., this amount of $\mathrm{Cd}$ in the medium stimulated its growth and reported the highest growth-rate and maximum population density than at any other concentration. This can be explained since there are some metals like $\mathrm{Cd}$ that can replace other elements such as $\mathrm{Ca}$ and $\mathrm{Fe}$, going through their specific transporters and carriers, getting into the cell. On the other hand, there is also evidence that suggests that in presence of cadmium, algae are able to produce polysaccharides on the cell wall as a protection mechanism against the heavy metal toxicity, which stimulates metabolic activity within the cell $[9,18,21]$. As a result, at low concentrations the heavy metal is not harmful for the microalgae and it does not affect negatively the cell growth.

Based on the dry weight data of Anikistrodesmus sp., from the one-way ANOVA, it was found that different 


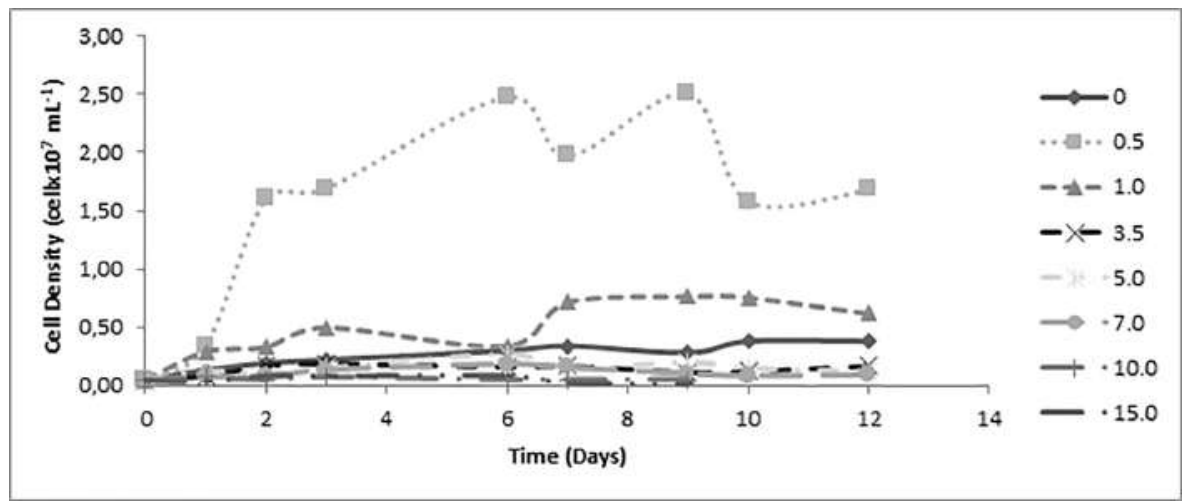

Figure 4 Effect of cadmium concentration on Chlorella sp. cell kinetics growing during 12 days of culture

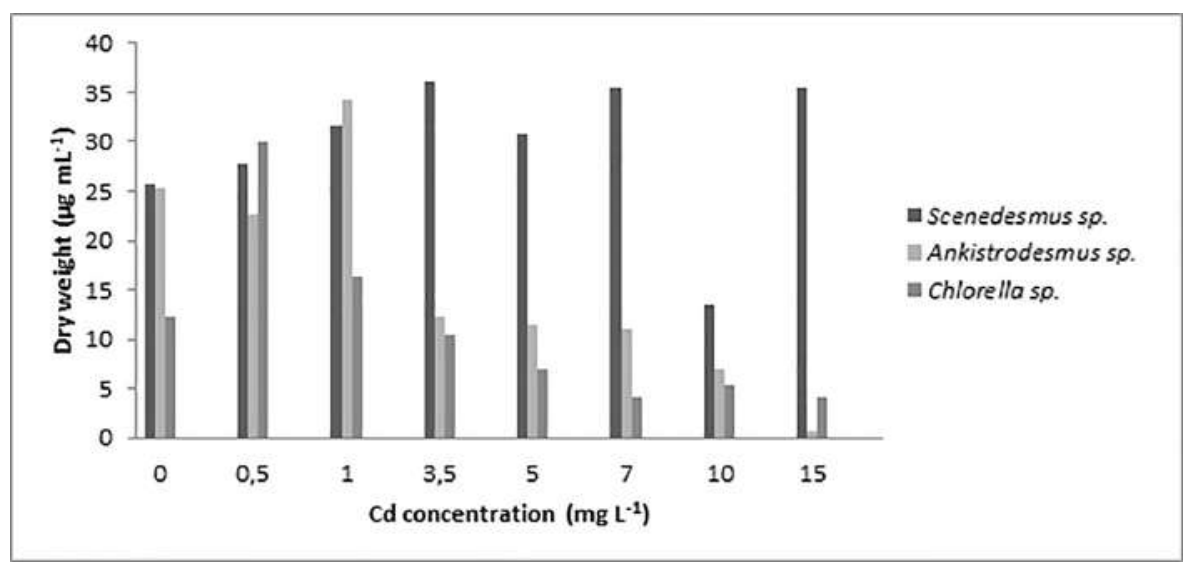

Figure 5 Total dry weight for the three strains of microalgae after 12 days of culture

concentrations of $\mathrm{Cd}$ have a significant influence on the values of total dry weight $(P$-value $<0.05)$. The highest value of the parameter reached by the microalgae was at a $\mathrm{Cd}$ concentration of $1.0 \mathrm{mg} \mathrm{L}^{-1}$ (Figure 5) and from this point, the inhibition of the culture growth starts to increase as the concentration of the heavy metal becomes greater.

For higher concentrations of the heavy metal Scenedesmus sp. is the microalgae with the highest biomass dry weight value, reaching its maximum (36.15 $\mu \mathrm{g} \mathrm{mL}^{-1}$ ) at a $\mathrm{Cd}$ concentration of $3.5 \mathrm{mg} \mathrm{L}^{-1}$. This indicates that the mentioned genus is more tolerant to higher heavy metal concentrations, which coincide with the values found in $\mathrm{LC}_{50}$ tests. Besides, it is consistent with the results found for Scenedesmus abundans where the response of this species at a $\mathrm{Cd}$ concentration range of $0.0-20.0 \mathrm{mg} \mathrm{L}^{-1}$ was analyzed, and negative effects were not observed on the viability of the cultures exposed to the heavy metal concentration up to $10.0 \mathrm{mg} \mathrm{L}^{-1}$ [22].

Based on the results obtained from the dry weight data of Chlorella sp., the highest biomass was achieved at a Cd concentration of $0.5 \mathrm{mg} \mathrm{L}^{-1}$. From Fisher's LSD test, it is shown that the culture at this particular concentration is statistically different from the other groups of $\mathrm{Cd}$ concentration (data not shown). From concentrations of $3.5 \mathrm{mg} \mathrm{L}^{-1}$ and higher Chlorella sp. is less tolerant to the heavy metal, that behavior is reflected on the biomass growth and in the low values of total dry weight.

\subsection{Cadmium effect on pigments}

Pigment analysis evidenced that chlorophyll concentration for the three strains was significantly affected by cadmium concentration in the medium $(P$-value $<0.05)$ and three homogenous groups were detected (Table 2). In this case, $\mathrm{Cd}$ concentration of $0.5 \mathrm{mg} \mathrm{L}^{-1}$ gave the highest concentration of chlorophylls reported in the present study, being the mean concentration of this pigment 1.15 $\mu \mathrm{g} \mathrm{mL}-1$.

The effect of $\mathrm{Cd}$ toxicity over the carotenoids and chlorophylls production is associated with the $\mathrm{Cd}$ concentration and genus of microalgae. Chlorophylls production at different $\mathrm{Cd}$ concentration have a similar behavior with the control not contaminated for Scenedesmus sp. (near $0.3 \mu \mathrm{g} \mathrm{mL}^{-1}$ ) (Data not shown). In general, pigments (chlorophylls and carotenoids) 
production is reduced for Scenedesmus sp. and Ankistrodesmus sp. at low concentrations of $\mathrm{Cd}$. However, Chlorella sp. reports higher chlorophylls production at $0.5 \mathrm{mg} \mathrm{L}^{-1} \mathrm{Cd}$ when compared with the control group. This behavior is related with the growth, indicating that low concentrations of $\mathrm{Cd}$ promote growth and pigment production in Chlorella sp.

The low cadmium tolerance presented by Ankistrodesmus sp. could be related to inhibition in the enzyme production, responsible for the catalysis that takes place in the biochemical reactions within cells [23], inhibition of protein synthesis and degradation of cell pigments, which interferes with photosynthesis and eventually causes death [24]. According to other researchers, Ankistrodesmus sp. is more likely to be found in waste water polluted with organic compounds, rather than environments with inorganic pollutants such as heavy metals. Nevertheless, some species of this genus, for instance $A$. braunii, have been studied for their capability to accumulate cadmium through the cell wall bonds for short periods of incubation $[25,26]$ although there is also important to consider the fact that the obtained response of this genus might be related as well to the genetic predisposition of the strain used for this study, and not only restrained to environmental conditions.

Chlorophylls and carotenoids participate in the capture of solar energy which is use for the synthesis of organic compounds necessary in cellular processes [27] and when expose to heavy metals, it is known that $\mathrm{Cd}$ is capable of being incorporated in green pigments forming heavy metal substituted chlorophylls, replacing $\mathrm{Mg}^{+2}$, which diminishes photosynthetic processes, behavior that has been observed in Scenedesmus quadricauda [28]. This is why, when analyzing the concentrations of these pigments in the study, it can be said that microalgae cellular processes were not much affected by lower $\mathrm{Cd}$ concentrations in the medium and just Scenedesmus sp. reported a better photosynthetic response at higher concentrations of the pollutant.

\subsection{Cadmium removal from the medium}

The highest removal percentage at low initial concentration in the medium (1.0 $\mathrm{mg} \mathrm{L}^{-1}$ ) was achieved by Chlorella sp. $18.07 \%$ compared with $5.13 \%$ removed by Scenedesmus $\mathrm{sp})$, however when the $\mathrm{Cd}$ concentration was increased to $7.0 \mathrm{mg} \mathrm{L}^{-1}$ Scenedesmus sp. reach a $32.74 \%$ of $\mathrm{Cd}$ removal on the culture media (Table 3 ).

It is known that Scenedesmus incrassatulus was able to remove the $24.1 \%$ of cadmium in water contaminated with $7.36 \mathrm{mgL}^{-1}$ of the metal [17], Scenedesmus abundans removed the $97.4 \%$ of cadmium in media with initial concentrations of $10 \mathrm{mgL}^{-1}$ metal, reaching a final concentration of $0.26 \mathrm{mg} \mathrm{L}^{-1}$ [22] for Chlorella vulgaris exposed to $3 \mathrm{mg} \mathrm{L}^{-1} \mathrm{Cd}$, removed between 51.4 and $96.5 \%$ [29] and for this same species, it was found that for very short periods of time it could remove $90 \%$ of the heavy metal in 30 minutes when suspended in alginate of sodium, and up to $90 \%$ of $\mathrm{Cd}$ when varying $\mathrm{pH}$ from 1 to 6 , reaching its maximum removal at 4.5 for $2 \mathrm{~h}[30,31]$. The percentages of removal reported in literature are higher than those found in this work, this is probably because they used strains previously exposed to some metal, different carbon sources, time of exposure, $\mathrm{pH}$ and other conditions which enhanced the microalgae tolerance to cadmium and the ability to remove it from the medium.

Regarding the maximum biomass density, total dry weight and pigment concentrations, Chlorella sp. reported a better response at lower $\mathrm{Cd}$ concentrations while Scenedesmus sp. behaves better at higher concentrations of the heavy metal which reflects higher tolerance of $\mathrm{Cd}$.

Microalgae $\mathrm{Cd}$ removal capacity obtained at high $\mathrm{Cd}$ concentration and $\mathrm{LC}_{50}$ values was related. It was observed that Chlorella sp. (with $\mathrm{LC}_{50} 8.0 \mathrm{mg} \mathrm{L}^{-1}$ of $\mathrm{Cd}$ ) had a lower removal percentage (equivalent to $8.6 \%$ ) than Scenedesmus sp. (with $\mathrm{LC}_{50} 20.0 \mathrm{mg} \mathrm{L}^{-1} \mathrm{Cd}$ ) which get a removal percentage of $32.74 \%$. This microalgal response supports that the native Scenedesmus sp. isolated could be a microalgae useful for $\mathrm{Cd}$ water bioremediation. Heavy metal tolerance of microalgae is a consequence of different cellular strategies including volatilization, accumulation or formation of chemical complex with extracellular compounds [32].

Chlorophytes cell wall is composed of polysaccharides, mainly cellulose [33]. Scenedesmus sp. has a cell wall composed of multiple layers and excretes extracellular polymeric substances with anionic properties; some heavy metals such as $\mathrm{Cd}$ can be accumulated in this cell wall [30], which acts as a cation exchanger bounding metallic cations; this behavior can be an advantage to limit the toxicity when the microalgae are exposed to great concentrations of the metal in the nature. In the case of Chlorella sp., the variation of the cell wall of a single species under different conditions can be very large, which makes it difficult to know exactly what kind of compounds are found in it [34], and the polysaccharides located in the cell wall might have different mechanism of reaction than the ones in Scenedesmus sp. cell wall and may not give a protectant effect that allows growth at greater $\mathrm{Cd}$ concentrations. Tolerance in some cases can also be due to transporter proteins which mediate heavy metal movements through membranes, and some of them are classified as cation diffusion facilitator (CDF) that are involved in the heavy metal homeostasis [35]. 
Table 2 Cd effect on microalgae pigments

\begin{tabular}{|c|c|c|c|c|c|c|}
\hline Parameters & $\begin{array}{l}\text { Scenedesmus } \\
\text { sp. }\end{array}$ & & $\begin{array}{l}\text { Chlorella } \\
\text { sp. }\end{array}$ & & Ankistrodesmus sp. & \\
\hline $\begin{array}{l}\text { Cd concentration } \\
\left(\mathrm{mg} \mathrm{L}^{-1}\right)\end{array}$ & 0 & 0.5 & 0 & 0.5 & 0 & 1.0 \\
\hline $\begin{array}{l}\text { Clorophylls } \\
\left(\mu \mathbf{g ~ m L}^{-1}\right)\end{array}$ & $0.32 \pm 0.08$ & $0.33 \pm 0.27$ & $0.56 \pm 0.30$ & $4.56 \pm 2.72$ & $1.33 \pm 0.10$ & $1.19 \pm 0.04$ \\
\hline $\begin{array}{l}\text { Carotenoids } \\
\left(\mu \mathrm{g} \mathrm{mL}^{-1}\right)\end{array}$ & $0.037 \pm 0.014$ & $0.016 \pm 0.004$ & $0.18 \pm 0.06$ & $1.12 \pm 0.68$ & $0.34 \pm 0.04$ & $0.30 \pm 0.06$ \\
\hline
\end{tabular}

Table 3 Cd removal percentage of Chlorella sp. y Scenedesmus sp.

\begin{tabular}{llll}
\hline Genus & $\begin{array}{l}\text { Initial } \\
\text { concentration } \\
\text { (mg L-1) }\end{array}$ & $\begin{array}{l}\text { Final } \\
\text { concentration } \\
\text { (mg L-1) }\end{array}$ & $\begin{array}{l}\text { Removal } \\
\text { percentage } \\
\text { (\%) }\end{array}$ \\
\hline \multirow{2}{*}{ Chroella sp. } & 1.0 & $0.92 \pm 0.082$ & 8.07 \\
& 7.0 & $6.39 \pm 0.16$ & 8.60 \\
\hline \multirow{2}{*}{ Scenedesmus sp. } & 1.0 & $0.95 \pm 0.05$ & 5.13 \\
& 7.0 & $4.71 \pm 1.81$ & 32.74 \\
\hline
\end{tabular}

Furthermore, this group of proteins can expulse from the cell cations such as $\mathrm{Cd}$ through ion exchange in a chemiosmotic process [36].

Colombia has a wide diversity of microalgae [37] with great potential for the treatment of water polluted with $\mathrm{Cd}$ or other heavy metals. Besides, the results found in the present study show important percentage of removal which can lead to more studies with other native microalgae species that can possibly generate a similar response towards $\mathrm{Cd}$ as it was found in this research.

\section{Conclusions}

The experimental results of this research show that Cd tolerance depends on the genus of microalgae as well as on the cadmium concentration in the culture medium. Ankistrodesmus sp. was the microalgae with the lowest resistance to $\mathrm{Cd}$ toxicity measured as $\mathrm{LC}_{50}$, while Chlorella sp. and Scenedesmus sp. had higher tolerance. Furthermore, growth biomass measured as total dry weight and growth curves show that at higher metal concentration Scenedesmus sp. is the one with the best response. In general, low $\mathrm{Cd}$ concentrations did not affect negatively the growth of microalgae and there was found positive response in Chlorella sp. Regarding the $\mathrm{Cd}$ removal, it was found that Scenedesmus sp. removed $32.74 \%$ of the heavy metal at $7.0 \mathrm{mg} \mathrm{L}^{-1}$ in the medium. Chlorella sp. had a removal percentage of $8.07 \%$, at an initial $\mathrm{Cd}$ concentration of $1.0 \mathrm{mg} \mathrm{L}^{-1}$ although it is relevant to perform removal kinetics in further studies in order to identify the accumulation processes that may occur in these microalgae.
With the strains of microalgae used in this study, it is recommended to make more comparative assays in mediums with different carbon sources in order to reach higher cell densities, it is also recommended to vary light and dark periods of exposition of the cultures, $\mathrm{pH}$ and temperature, expose microalgae to gradual concentration of $\mathrm{Cd}$ and compare the percentage removal with the results obtained in this study, and use microalgae previously exposed to $\mathrm{Cd}$ or another heavy metal since these are strains that possibly develop higher tolerance to greater heavy metal concentrations and might have major removal percentage.

\section{Acknowledgements}

The authors thank the University of Medellín for supporting this project. Furthermore, they thank the GRINBIO human team for their active participation in the experimental development of the project. They also express their gratitude to the laboratory center and the Engineering Research Center (in Spanish CEIN) of the University of Medellín for its support.

\section{References}

[1] S. Wakelin and et al, "Mechanisms of pollution induced community tolerance in a soil microbial community exposed to cu," Environmental Pollution, vol. 190, July 2014. [Online]. Available: https://doi.org/10.1016/j.envpol.2014.03.008

[2] P. Le Cloirec and A. Yves, "Bioremediation of heavy metals using microorganisms," in Bioremediation of aquatic \& terrestrial ecosystems, M. Fingerman and R. Nagabhushanam, Eds. Taylor y Francis Group, 2005, pp. 97-105. 
[3] C. Nagata and et al, "Associations of urinary cadmium with circulating sex hormone levels in pre- and postmenopausal japanese women," Environmental Research, vol. 150, October 2016. [Online]. Available: https://doi.org/10.1016/j.envres

[4] N. Mancera and R. Álvarez, "Estado del conocimiento de las concentraciones de mercurio y otros metales pesados en peces dulceacuícolas de colombia," Acta Biológica Colombiana, vol. 11, no. 1, pp. 3-23, ene 2006.

[5] T. Ha, S. Burwell, M. Goodwin, J. Noeker, and S. Heggland, "Pleiotropic roles of ca+2/calmodulin-dependent pathways in regulating cadmium-induced toxicity in human osteoblast-like cell lines," Toxicology Letters, vol. 260, October 17 2016. [Online]. Available: https://doi.org/10.1016/j.toxlet

[6] K. So and S. Oh, "Cadmium-induced heme-oxygenase-1 expression plays dual roles in autophagy and apoptosis and is regulated by both pkc- $\delta$ and pkb/akt activation in nrk52e kidney cells," Toxicology, vol. 370, August 30 2016. [Online]. Available: https: //doi.org/10.1016/j.tox

[7] H. Ge and et al, "Effect of microalgae with semicontinuous harvesting on water quality and zootechnical performance of white shrimp reared in the zero water exchange system," Aquacultural Engineering, vol. 72, pp. 70-76, 2016.

[8] N. Abdel, A. Al-Homaidan, and I. Ibraheem, “Microalgae and wastewater treatment," Saudi Journal of Biological Sciences, vol. 19, no. 3, July 2012. [Online]. Available: https://doi.org/10.1016/j.sjbs. 2012.04 .005

[9] A. Cortés, S. Sanchez, and M. Bartolomé, "Mecanismos de resistencia a metales tóxicos (cd) bajo variaciones abióticas en microalgas," TIP Revista Especializada en Ciencias Químico-Biológicas, vol. 21, no. 1, pp. 40-52, 2018.

[10] M. Castañeda. (2004) Microbiología aplicada: Manual de laboratorio. Universidad Autónoma Metropolitana. México D.F. [Online]. Available: http://zaloamati.azc.uam.mx/bitstream/handle/ 11191/1746/Microbiologia_aplicada_manual_de_laboratorio.pdf? sequence $=3$ \&is Allowed $=y$

[11] C. van Leewuen and T. Vermeire. (2007) Risk assessment of chemicals: An introduction. [Springer]. [Online]. Available: http://www.acad.bg/ebook/cheminformatics/van\%20Leeuwen_ Risk\%20Assessment $\% 20$ of\%20Chemicals-An\%20Introduction\% 202nd\%20ed.pdf

[12] Y. Pica, A. Ronco, and M. Díaz, "Ensayo de toxicidad crónica con el alga selenastrum capricornutum (pseudokirchneriella subcapitata) por el método de enumeración celular basado en el uso de hemocitómetro neubauer," in Ensayos toxicológicos para la evaluación de sustancias químicas en agua y suelos. La experiencia en México, P. Ramírez and A. Mendoza, Eds. México, D.F.: Secretaría de Medio Ambiente y Recursos Naturales (SERMANAT), 2008, pp. 69-87.

[13] R. Crippen and J. Perrier, "The use of neutral red and evans blue for live-dead determinations of marine plankton," "Stain Technology, vol. 49, no. 2, pp. 97-104, Mar. 1974

[14] B. Arredondo and D. Voltolina, "Determinación de peso seco y contenido orgánico e inorgánico," in Métodos y Herramientas Analíticas en la Evaluación de la Biomasa Microalgal, B. Arredondo and D. Voltolina, Eds. La Paz, BO: Centro de Investigaciones Biológicas del Noroeste, 2007, pp. 27-30.

[15] B. Arredondo and D. Voltolina, "Determinación de pigmentos por espectrofotometría," in Métodos y Herramientas Analíticas en la Evaluación de la Biomasa Microalgal, B. Arredondo and D. Voltolina, Eds. La Paz, BO: Centro de Investigaciones Biológicas del Noroeste, 2007, pp. 59-68.

[16] A. P. H. A. (APHA)", Standard Methods for the examination of water and wastewater, 21st ed. Washington, USA: American Public Health Association, 2005.

[17] J. Peña, F. Martínez, F. Esparza, and R. Cañizares, "Heavy metals removal by the microalga scenedesmus incrassatulus in continuous cultures," Biosource Technology, vol. 94, no. 2, pp. 219-222, Sep. 2004.

[18] S. Nam, W. Lee, and Y. An, "Derivation of ecological protective concentration using the probabilistic ecological risk assessment applicable for korean water environment: (i) cadmium," Toxicological
Research, vol. 28, no. 2, June 2012. [Online]. Available: https: //doi.org/10.5487/TR

[19] H. Ouyang and et al, "Effects of five heavy metals at sub-lethal concentrations on the growth and photosynthesis of chlorella vulgaris," Chinese Science Bulletin, vol. 57, no. 25, pp. 3363--3370, Sep. 2012.

[20] Z. Huang and et al, "Growth-inhibitory and metal-binding proteins in chlorella vulgaris exposed to cadmium or zinc," Aquatic Toxicology, vol. 91, no. 1, January 18 2009. [Online]. Available: https: //doi.org/10.1016/j.aquatox

[21] L. Andrade and et al, "Brown algae overproduce cell wall polysaccharides as a protection mechanism against the heavy metal toxicity," Marine Pollution Bulletin, vol. 60, no. 9, September 2010. [Online]. Available: https://doi.org/10.1016/j.marpolbul

[22] P.Terry and W. Stone, "Biosorption of cadmium and copper contaminated water by scenedesmus abundans," "Chemosphere, vol. 47, no. 3, pp. 249-55, Apr. 2002.

[23] D. voet and J. Voet, Bioquímica, 3rd ed. Buenos aires, Arg.: Editorial Médica Panamericana, 2006.

[24] A. Xiao and et al, "Carbon and metal quantum dots toxicity on the microalgae chlorella pyrenoidosa," Ecotoxicology and Environmental Safety, vol. 133, November 2016. [Online]. Available: https: //doi.org/10.1016/j.ecoenv.2016.07.026

[25] N. Jafari and V. Gunale, "Hydrobiological study of algae of an urban freshwater river," Journal of Applied Sciences and Environmental Management, vol. 3, no. 2, pp. 153-158, Jun. 2006.

[26] S. Subashchandrabose, B. Ramakrishnan, M. Megharaj, K. Venkateswarlu, and R. Naidu, "Mixotrophic cyanobacteria and microalgae as distinctive biological agents for organic pollutant degradationr," Environment International, vol. 51, january 2013. [Online]. Available: https://doi.org/10.1016/j.envint.2012.10.007

[27] L. Taiz and E. Zeiger, Fisiología vegetal, 1st ed. Castellón de la Plana, Esp.: Universitat Jaume I, 2006.

[28] T. Pfeiffer, I. Camagajevac, D. Maronic, and I. Maksimovic, "Regulation of photosynthesis in algae under metal stress," in Environment and Photosynthesis: A Future Prospect, V. Singh, S. Singh, R. Singh, and S. Prasad, Eds. New Delhi, IN: Studium Press, 2018, pp. 261-286.

[29] A. El-Naggar and M. El-Sheekh, "Abolishing cadmium toxicity in chlorella vulgaris by ascorbic acid, calcium, glucose and reduced glutathione," Environmental Pollution, vol. 101, no. 2, 1998. [Online]. Available: https://doi.org/10.1016/S0269-7491(98)00089-X

[30] A. Cantú, L. Morales, K. Arevalo, M. Garza, and I. Balderas, "Cadmium(ii) and lead(ii) removal by chlorella sp. immobilized and e. coli genetically engineered with mice metallothionein i," MRS Online Proceedings Library Archive, vol. 1277, february 12011. [Online]. Available: https://doi.org/10.1557/PROC-1278-S07-P3

[31] M. Kumar, A. Singh, and M. Sikandar, "Study of sorption and desorption of cd (ii) from aqueous solution using isolated green algae chlorella vulgaris," Applied Water Science, vol. 8, no. 225, november 16 2018. [Online]. Available: https://doi.org/10.1007/ s13201-018-0871-y

[32] R. Lee. (2008) Phycology. [Cambridge University Press]. [Online]. Available: http://www.dbbe.fcen.uba.ar/contenido/ objetos/PhycologyLee_1395342784413494.pdf

[33] J. Voigt, A. Stolarczyk, M. Zych, P. Malec, and J. Burczyk, "The cell-wall glycoproteins of the green alga scenedesmus obliquus. the predominant cell-wall polypeptide of scenedesmus obliquus is related to the cell-wall glycoprotein gp3 of chlamydomonas reinhardtii," Plant Science, vol. 215-216, february 2014. [Online]. Available: https://doi.org/10.1016/j.plantsci.2013.10.011

[34] H. Gerken, B. Donohoe, and E. Knoshaug, "Enzymatic cell wall degradation of chlorella vulgaris and other microalgae for biofuels production," Planta, vol. 237, no. 1, january 2013. [Online]. Available: https://doi.org/10.1007/s00425-012-1765-0l

[35] N. Das, S. Bhattacharya, and M. Maiti, "Enhanced cadmium accumulation and tolerance in transgenic tobacco overexpressing rice metal tolerance protein gene osmtp1 is promising for phytoremediation," Plant Physiology and Biochemistry, vol. 105, august 2016. [Online]. Available: https://doi.org/10.1016/j.plaphy. 
D. Duque et al., Revista Facultad de Ingeniería, Universidad de Antioquia, No. 92, pp. 60-69, 2019

2016.04.049

[36] C. Cervantes and et al, "Interacciones microbianas con metales pesados," Revista Latinoamericana de Microbiología, vol. 48, no. 2, pp. 203-210, Apr. 2006.

[37] M. Arcos and A. Gómez, "Microalgas perifíticas como indicadoras del estado de las aguas de un humedal urbano: Jaboque, Bogotá D.C., Colombia," NOVA, vol. 4, no. 6, december 12 2006. [Online]. Available: https://doi.org/10.22490/24629448.362 